\title{
IS THE SKY FALLING ON THE CONTENT INDUSTRIES?*
}

\author{
MARK A. LEMLEY**
}

Are the content industries doomed? They certainly seem to think so. The music industry tells us, as their revenues decline because of file sharing, "we can't compete with free," and so we're history. No one is going to create new music anymore. The video industries seem to be getting in on the act, too. They've showed up behind closed doors in Washington, D.C. to complain about the prospect of a national broadband plan, because broadband is simply going to make it easier for people to pirate video over the Internet. "We've got to do something about it," they tell us, "or no one is going to make movies anymore."

And now, as you've read from Mark Cooper, newspapers are in on the act as revenues decline. ${ }^{1}$ Print journalism is dying, people are leaving the business in droves because "we can't compete with free." Though here, curiously, the free is their own free. The complaint of the newspapers is that they can't compete with themselves putting their own material on the Internet for free.

This sounds like a pretty alarming story. But this is not the first time the content industries have told us that they face imminent disaster. I sometimes suspect there was an association of monastic scriveners who protested the printing press on the theory that it was going to destroy the beautiful hand illumination of manuscripts. Which, of course, it did. But, it did not, as a result, destroy the book industry. In fact, it rather expanded that industry.

I do know that artists in the 19th century complained about photographs because who was then going to pay them to paint portraits of people? Who's going to want photorealistic artistic portrayals of landscapes if you can just have a machine do the same thing? Artists, we

* (C) 2011 Mark A. Lemley.

** William H. Neukom Professor of Law, Stanford Law School; partner, Durie Tangri LLP. Thanks to Paul Goldstein, Rose Hagan, Fred von Lohmann, Madhavi Sunder, and participants at the Silicon Flatirons conference, the Liberation Technology seminar, and a workshop at Stanford Law School for helpful comments. This is a transcript of a speech and reads like it.

1. Mark Cooper, Structured Viral Communications: The Political Economy and Social Organization of Digital Disintermediation, 9 J. TELECOMM. \& High TECH. L. 38 (2011). 
were told, would be driven out of the profession in droves, and art would wither and die. ${ }^{2}$ Photography did, of course, change the art world. But it arguably changed it for the better. And in any event, the benefits of the addition of the camera to the repertoire of art surely outweigh the costs.

Moving into the 20th century, the claims about technology as a threat to content came fast and furious. The threats in the first decades of the 20th century were the player piano and the gramophone. John Philip Sousa wrote an article, The Menace of Mechanical Music, ${ }^{3}$ in which he argued that those infernal devices were a "threat to his livelihood, to the entire body politic, and to 'musical taste' itself. . . The player piano and the gramophone [ ] strip[ ] life from real, human, soulful live performances." And he articulated an argument that is going to sound familiar to any of you who have been in the copyright industry:

Do they not realize that if the accredited composers, who have come into vogue by reason of merit and labor, are refused a just reward for their efforts, a condition is almost sure to arise where all incentive to further creative work is lacking, and compositions will no longer flow from their pens...? What, then, of the playing and talking machines? ${ }^{5}$

In other words, without some way for musicians to continue to get paid as they had been paid before (by selling sheet music), no one will create content.

Interestingly, Sousa's concern was not with professional content creators. Notwithstanding the previous passage, his real concern was that amateur music-making was threatened by the rise of a professional musical class that could lead to the rampant destruction of the country. He wrote,

$[\mathrm{u}]$ nder such conditions the tide of amateurism cannot but recede, until there will be left only the mechanical device and the professional executant. Singing will no longer be a fine accomplishment; vocal exercises, so important a factor in the curriculum of physical culture, will be out of vogue! Then what of the national throat? Will it not weaken? What of the national chest? Will it not shrink?"

2. Painter Paul Delaroche reportedly declared, on seeing his first daguerreotype, "From today painting is dead." STEPHEN BANN, PAUL DELAROCHE: HiSTORY PAINTED 9 (1997). (1906)

3. John Philip Sousa, The Menace of Mechanical Music, 8 APPLETON's MAG. 278

4. Nate Anderson, 100 Years of Big Content Fearing Technology - In Its Own Words, ARS TECHNICA, Oct. 11, 2009, http://arstechnica.com/tech-policy/news/2009/10/100-years-ofbig-content-fearing-technologyin-its-own-words.ars.

5. Sousa, supra note 3, at 284 .

6. Id. at 281. 
The worry was that amateur musicians would disappear, taken over by professionals who could afford to produce music using this technology.

Did we destroy the music industry by introducing the gramophone? Not so much.

In fact, 20 years later, the next imminent threat to the demise of the content industries came from radio. Curiously, the threat from radio was that it was going to steal the very revenues that that gramophone industry had in the previous 20 years generated for musicians. Nonetheless, because radio is available for free to all, because no one charges for it, we started to hear the emergence of the argument that you can't compete with free. If radio is allowed, the argument went, pirate radio will destroy the music industry because who would buy music with real money when they could just listen to it on the radio for free?

That turned out also to be not so true. It seems that perhaps you can compete with free. ${ }^{7}$ Certainly consumers starting in the 1920 s were perfectly happy to buy music notwithstanding the availability of that very music on the radio for free.

Switching channels to the video industry, by the late 1950s and the 1960s, the television industry was threatened by another bogeyman that was going to destroy television. The existing business model was providing broadcast television for free; the threat was cable television. Note the irony here. The argument was not that paid content can't compete with free, the argument is free content can't compete with paid. If we don't shut down the cable television industry, no one will bother to produce new television shows, and there won't be anything to go on cable. This is an argument that made it all the way to the United States Supreme Court in the Fortnightly case $^{8}$ and led to a decision that brought us within two votes of shutting down the cable television industry unless it had the permission of the television broadcasters. ${ }^{9}$

Ironically, of course, not only did we not shut down television as a result of introducing cable television, it is now broadcast stations who fight to get on cable networks, going to court again to demand that they be included on cable television because that will expand their market. ${ }^{10}$

7. As Mike Masnick put it, "saying you can't compete with free is saying you can't compete period.” (Mike Masnick, Saying You Can't Compete With Free Is Saying You Can't Compete Period, TECHDIRT (Feb. 15, 2007, 12:41 PM), http://www.techdirt.com/articles/20070215/002923.shtml).

8. Fortnightly Corp. v. United Artists Television, Inc., 392 U.S. 390 (1968).

9. The district court and the court of appeals had held cable television to be copyright infringement. Five Supreme Court Justices voted to reverse that decision, but only six participated in the case. Id. at 402.

10. See Turner Broad. Sys., Inc. v. FCC, 520 U.S. 180 (1997) (upholding the constitutionality of a law that required cable companies to carry local broadcast television on their wires, finding that without the law many of them would not have done so). 
By the 1970s the big action was in the photocopier. The photocopier, like the printing press, the camera, the record player, radio, and cable television, permitted people to replicate things they would otherwise have to pay for, namely books. No less an authority than Melville Nimmer, the leading copyright scholar, wrote, "the day may not be far off when no one need purchase books." 11 That was in 1972. So the copyright industries tried to shut down the photocopier; suing in the Williams E Wilkins case to try to prevent the widespread copying by federal government institutions of books and journal articles. ${ }^{12}$ Again the content industries made it to the Supreme Court and were barely foiled, here by an equally divided Court. ${ }^{13}$ The photocopying of journal articles was (barely) allowed.

Books and journal articles did not disappear in the early 1970s. Instead they seemed to thrive during that time, notwithstanding the existence of a technology that allows people to take them for free.

By the late 1970s we get to the example that is perhaps the most familiar: the VCR. The free television model, augmented by cable, had been established for some time. Along came a technology that allowed people to copy this freely provided television content and do what they wanted with it. The content industry warned us that the VCR must be stopped. Here is Jack Valenti of the MPAA, speaking to Congress:

[T] he VCR is stripping...those markets clean of our profit potential, you are going to have devastation in this marketplace.... We are going to bleed and bleed and hemorrhage, unless this Congress at least protects one industry that is able to retrieve a surplus balance of trade and whose total future depends on its protection from the savagery and the ravages of this machine. ${ }^{14}$

If that were not enough, he went on to say, "I say to you that the $\mathrm{VCR}$ is to the American film producer and the American public as the Boston strangler is to the woman home alone." 15 The industry's position was that if Congress didn't shut down the infernal machine that was the VCR, if they didn't prevent people from making copies, no one would make movies.

This argument carried the day in the Ninth Circuit, which held the

11. Copying v. Copyright, TIME, May 1, 1972, at 62 (quoting Melville Nimmer).

12. Williams \& Wilkins Co. v. United States, 487 F.2d 1345 (Ct. Cl. 1973) (en banc), aff $d$ by an equally divided court, 420 U.S. 376 (1975).

13. Williams \& Wilkins Co. v. United States, 420 U.S. 376, 376 (1975).

14. Home Recording of Copyrighted Works: Hearings on H.R. 4783, H.R. 4794, H.R. 4808, H.R. 5250, H.R. 5488, and H.R. 5705 Before the Subcomm. on Courts, Civil Liberties, and the Admin. of Justice of the H. Comm. on the Judiciary, 97th Cong. 8 (1982) (testimony of Jack Valenti, President, Motion Picture Association of America, Inc.).

15. Id. 
VCR illegal. ${ }^{16}$ It then went to the Supreme Court, which heard the case twice. The Court was at first inclined to affirm the Ninth Circuit's conclusion and ban the VCR, but ultimately decided, by a 5-4 vote, that the VCR was okay. ${ }^{17}$

Did content suffer as a result? Not exactly. In fact, it turns out that through the 1980s and 1990s it was the very VCR and its successor, the DVD player, which were going to destroy the broadcast and movie industries, that kept them alive, generating $\$ 30$ billion in revenues by 2002 for the industries. ${ }^{18}$

Back on the audio front, at about the same time, the content industry was concerned about audio cassettes. The gramophone records, which themselves didn't destroy the industry, and which survived the ravages of radio, were now threatened by audio cassettes because people could tape music off the radio. While listening to the radio for free turned out not to shut the music industry down, listening to the radio, taping the songs, and listening to those songs whenever you wanted to was certainly going to shut it down.

So, the industry started an ad campaign to try to shut down audio cassettes featuring a skull and crossbones in the shape of an audio cassette tape. The tag line was "Home Taping is Killing Music and It's Illegal." ${ }^{19}$ But we didn't ban home taping, and it turns out that music sales continued to go up through the 1980s and the 1990s, notwithstanding the threat of home taping and the possibility that people could have for free what they otherwise would have to pay for. ${ }^{20}$

16. Universal City Studios, Inc., v. Sony Corp. of Am., 659 F.2d 963, 976 (9th Cir. 1981) ("The district court determined that an injunction would not be an appropriate remedy. The court should reconsider this action." (internal citation omitted)).

17. Sony Corp. of Am. v. Universal City Studios, Inc., 464 U.S. 417, 456-57 (1984).

18. Digital HollyWOOd, KEYNOTE SPEAKER BIO, WARREN LiEBERFARB (2005), available at http://www.digitalhollywood.com/\%231DHFall05/DVDOne.html.

19. For a collection of this and many other fabulous examples, see Anderson, supra note 4.

20. In fact, the 1980s began a dramatic expansion of music sales that continued until the late 1990s, when the number of albums sold began to decline as consumers switched to digital music. Press Release, Bridge Ratings, U.S. Music Consumption: How Many Are Buying \& Who's Listening? (Aug. 29, 2007), http://www.bridgeratings.com/press_08.29.2007MusicConsumption.htm. 


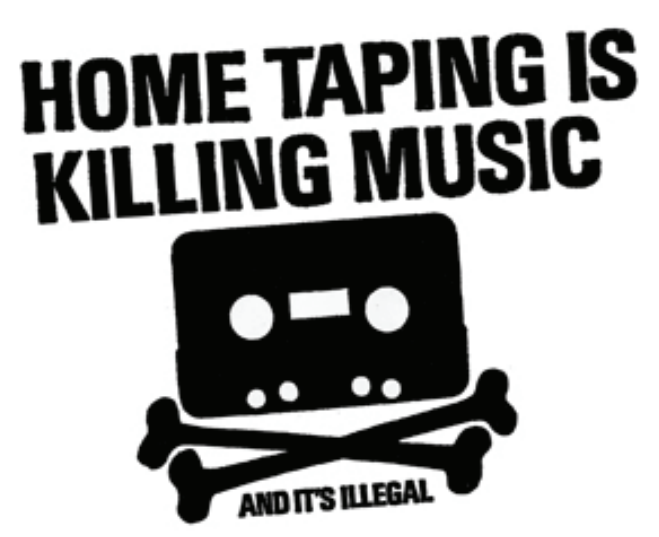

We did, however, successfully shackle the next-generation of audio technology in the early 1990s with the digital audio tape. Here the perceived threat was the same as audio cassettes but worse. Audio cassettes turned out not to have shut down the industry, true. But if you gave customers digital audio cassettes, content owners warned, if you allowed them to make a digital-quality copy, then they had no reason to buy our better quality copy, and we will be shut down. That argument carried the day in Congress. Digital audio tapes were then subject to a compulsory licensing scheme and were never heard from again by massmarket consumers. ${ }^{21}$ The technology flopped once it was put under the control of the content industry.

By the late 1990s the same arguments were made against the latest digital scourge, the MP3 player. We have to shut down the MP3 players, we were told, because the Rio, Diamond Multimedia's first-generation player, was designed to undermine the creation of a legitimate digital distribution marketplace. The MP3 player threatened to provide digital content when consumers wanted it. Consumers who could create their own digital content from their CDs wouldn't buy digital content from the content industries-not that those industries were actually offering digital content at the time, but just in case they wanted to in the future.

So the music industry sued to shut down the MP3 player. That suit failed in the 9th Circuit in the RLAA v. Diamond Multimedia case. ${ }^{22} \mathrm{MP} 3$ players took off, and people started to load them with content. And yes, it is true that a lot of that content was unlawfully copied, but the owners of MP3 players also spent a lot of money buying CDs at the end of the 1990s. But then along came Napster, which, the RIAA told us once again, was going to shut down the music industry. Digital music must be

21. 17 U.S.C. $\S \S 1001-1007$ (2006).

22. Recording Indus. Ass'n of Am. v. Diamond Multimedia Sys., Inc., 180 F.3d 1072 (9th Cir. 1999). Ironically, the suit failed because the court concluded that MP3 players were immunized by a provision in the Copyright Act, 17 U.S.C. $§ 1008$, passed in 1992 as part of an effort to regulate digital audio tape, which created a home taping exemption to copyright infringement. Id. at 1079 . 
stopped. The RIAA fought a delaying action for years to try to do this, but they ultimately lost. They did win their individual cases; they shut down Napster ${ }^{23}$ and they later shut down Grokster ${ }^{24}$ and Limewire. ${ }^{25}$ They did not shut down digital music distribution. When, a decade later, they ultimately gave in and offered it, it turned out people were actually willing to buy their digital music. In April 2008, Apple surpassed WalMart as the largest retailer of music in the country. ${ }^{26}$ And by 2008 , there were more legal music sales of all types than ever before in history; 70\% were digital downloads. ${ }^{27}$ Digital music in general is not in fact the threat it seemed to be.

Meanwhile, back in the video space, the world had moved on to DVRs. VCRs, well, maybe they didn't turn out to be that bad-maybe they actually helped us a lot - but digital video recorders, those are really bad. DVRs were really bad, we were told, because people were going to skip the commercials. The CEO of Turner Broadcasting, Jamie Kellner, said of the DVR and commercial skipping, "It's theft. Your contract with the network when you get the show is you're going to watch the spots. Otherwise you couldn't get the show on an ad-supported basis. Any time you skip a commercial . . you're actually stealing the programming." 28

Notwithstanding the rampant theft by bathroom-goers everywhere, and the success of the video industry in shutting down RePlayTV, the first entrant into this market, ${ }^{29} \mathrm{TiV}$ o succeeded, and, it turns out, didn't destroy the television industry. Instead, it revitalized that industry because a lot of people like me who didn't watch television suddenly discovered that when they could choose when and where they wanted to see their programming, there was actually a bunch of good stuff on. And the 2000s became the Golden Age of television.

There are examples going on right now as well. Digital radio is my personal favorite because the original pirates in the radio industry are now trying very hard to shut down competition by digital and Internet radio, the next generation of pirates. Digital television is another example; the FCC told us on the basis of representations by the TV

23. A\&M Records, Inc. v. Napster, Inc., 239 F.3d 1004, 1027 (9th Cir. 2001).

24. Metro-Goldwyn-Mayer Studios, Inc. v. Grokster, Ltd., 545 U.S. 913, 941 (2005).

25. Arista Records LLC v. Lime Group LLC, No. 06 CV 5936 (KMW), 2010 WL 2291485, at*8 (S.D.N.Y. May 25, 2010).

26. Press Release, Apple, iTunes Store Top Music Retailer in the US (Apr. 3, 2008), http://www.apple.com/pr/library/2008/04/03itunes.html.

27. Ken Barnes, Music Sales Boom, but Albums Fizzle, USA TODAY, Jan. 2, 2009, at 6D.

28. Anderson, supra note 4 (quoting Staci D. Kramer, Content's King, CABLEWORLD, Apr. 29, 2002).

29. See Newmark v. Turner Broad. Network, 226 F. Supp. 2d 1215 (C.D. Cal. 2002). The case against SONICBlue, the maker of the RePlayTV, settled without an opinion when the company was driven into bankruptcy. See Paramount Pictures Corp. v. RePlayTV, 298 F. Supp. 2d 921 (C.D. Cal. 2004). 
industry that in the absence of some protection mechanism, high-value content would be withheld from broadcast television and would migrate to pay services. Notwithstanding this claim, we did ultimately, after a 22year odyssey, move to digital television in 2009. Perhaps television and radio are now doomed too, but I'm not holding my breath. Pornographers complain of a once-lucrative market now flooded by amateur pornography; even sex fears it can't compete with free. ${ }^{30}$ But I wouldn't list "lack of sufficient pornography" as among our larger societal problems.

The content industry, it seems, has a Chicken Little problem.

It may, in fact, be the case that this time the sky is falling. But, if you claim that the sky is falling whenever a new technology threatens an existing business model, the rest of the world can be forgiven for not believing you when you claim that this time around it's going to be different. Now, let's be clear, each of these technologies changed the business model of the industry. They caused certain revenue streams to decline. But they also opened up new ones.

So how is the content industry going to survive? Let me offer a few suggestions:

First off, what won't work.

I think it is pretty clear that shutting down the technology doesn't work. Whenever you succeed in shutting down a technology that people want, companies develop a different technology that responds to that market demand.

Locking down the technology doesn't usually work either. Almost every time we impose digital rights management, as we did with computer dongles, or digital audio tape, or the Sony minidisc, or the DivX alternative to the DVD player, or the DRM in digital music, either the technology or the digital rights management fails because the controls are inconvenient and they get in the way. In the rare instances in which a locked-down technology succeeded (the DVD is the prime example), it is because the technology was so much better than the status quo that people would tolerate some inconvenience. And even then, it is worth noting that the technology that won the standards competition was the less restrictive of the two possible technologies.

None of this is to suggest that copyright law has no role to play. In many of the examples I've given, the technology ultimately came within the purview of copyright law, often with some sort of compulsory or collective license that allowed copyright owners to get paid without shutting down the technology or bringing the full weight of copyright

30. Kal Raustiala \& Chris Sprigman, Copyright Infringements in the Porn Industry,

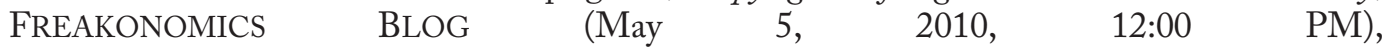
http://freakonomics.blogs.nytimes.com/2010/05/05/copyrighting-porn-a-guest-post. 
remedies to bear. Cable and satellite television ended up with a compulsory license, for instance; ${ }^{31}$ radio got a government-supervised but privately-organized collective licensing regime ${ }^{32}$ as well as an exemption from having to pay sound recording copyright owners. ${ }^{33}$ But the general lesson is that "mother, may I?" innovation regimes in which no one can develop a new technology unless they get the collective permission of all the content owners whose content might be distributed with that technology are not going to work.

Nonetheless, I think there are a number of circumstances and business models that are worth some serious exploration as at least partial solutions.

One is advertising. Now, I think that advertising has its limits as a business model. The current trend seems to be "alright, we'll make everything available for free since that seems to be what we have to do, but we'll make it up in advertising." There is a substantial amount of advertising revenue that can be found online - ask Google - but there are also limits to that business model. If the only people advertising are other content owners counting on advertising for their free products, the revenue has got to be coming from somewhere.

More important are lowered production costs. Mark Cooper talked about this eloquently. ${ }^{34} \mathrm{I}$ won't go in to more detail here except to point out that the digital revolution in the last decade has led to the largestever increase in the amount of content available in the world. We get far more video content because of YouTube than we have ever had before. We get far more text content because of blogging than we have ever had before. We get that new content because it is much easier and cheaper to make and distribute it. Now cheap production and distribution won't necessarily give us all the kinds and quality of content we want. But they give us an enormous array of content to choose from that wasn't available in a world in which all content had to be professionally produced, packaged into a disk, and shipped around the world in a truck.

Third, technology can change people's relationship to content in ways that can make a profit. You also see technological advances redounding to the benefit of content industries in various respects. If you have not seen Avatar, you should. And if you are going to see Avatar, you should absolutely see it in $3-\mathrm{D}$ in a movie theatre because the experience you have at home will not be the same experience. Not

31. 17 U.S.C.S. $\S \S 111,119$ (2010).

32. See United States v. Am. Soc'y of Composers, Authors \& Publishers, No. 13-95, 1941 U.S. Dist. LEXIS 3944 (S.D.N.Y. Mar. 4, 1941).

33. 17 U.S.C.S. $§ 114(2010)$.

34. Cooper, supra note 1, at 28-30. 
surprisingly, Avatar is the highest-grossing movie ever, ${ }^{35}$ and helped make 2009 the best financial year ever for the movie industry. ${ }^{36}$

Business models can also build on the experiential relationships that people have with content. People don't go see movies-at least good movies - and then stop thinking about them. People want to be engaged with their content. They want to have connections with the musicians they like. They want to go to concerts and experience music live. They want to engage in an ongoing relationship, and there's revenue there to be had by meeting that demand-providing that collaborative experience can be lucrative. You don't have to worry nearly as much about piracy if you are a maker of a massive multiplayer online role-playing game because the point of the game is largely the experience of interacting with all of the other people in the game. If you play a pirated version of World of Warcraft, you do not get the same experience as if you play World of Warcraft, because you aren't interacting with the people playing the official version.

One of the things content owners have lost in the digital world is the first-mover advantage. The duration of the advantage of being the first in the market with a product has gotten a lot shorter, as it is now much easier to copy things. But first-mover advantages do still exist, and companies can capitalize on them through branding. You can build a substantial revenue model out of having a brand and having a reputation for quality content, even if there are others providing competing content.

Companies can also make money by providing convenience to users. It turns out that many of the people who take content for free are often people of low socio-economic status; they're young, they're students. People who have substantial means often pay for things - even things that they could get for free. There's a Web comic called XKCD that actually makes a living selling books and T-shirts of the comics that it makes available online for free. ${ }^{37}$ Why is this? Because if you really like XKCD — and you should - you're willing to pay to have a physical book in your hand or to wear a T-shirt.

In the news media, too, I think there are revenue models to be had that spring from this explosion of content. Because the explosion of content comes with a wide array of quality from very good to very bad, there are business models to be had in enabling people to figure out what

35. Shadra Beesley, 'Avatar' Sinks 'Titanic' Best-Selling Record, MONEYBLOG (Jan. 26, 2010), bestselling-record. http://personalmoneystore.com/moneyblog/2010/01/26/avatar-sinks-titanic-

36. Press Release, Motion Picture Association of America, Inc., Worldwide Box Office Continues to Soar; U.S. Admissions on the Rise: 3D Gives a Boost to Box Office Growth (March 10, 2010), http://www.mpaa.org/resources/756f90f0-f982-49d7-9f0235da3773cc8c.pdf (on file with Journal on Telecommunications and High Technology Law).

37. XKCD Store, http://store.xkcd.com (last visited Oct. 16, 2010). 
is desirable and what is not, what is trustworthy and what is not. The role of the media may become, in part, a credentialing role, one that says this is, in fact, information that you can trust; this is, in fact, a video you will like. And that's a service for which people will pay even though the underlying content is free.

It may even be the case that copying drives creativity in unusual ways. Kal Raustiala and Chris Sprigman have suggested that the fashion industry benefits from the absence of copyright protection, because knock-off fashions serve both to popularize the original ones and eventually to drive demand to replace them. ${ }^{38}$ Both dynamics may work in other content industries. Up-and-coming musicians may like piracy if it builds their name recognition, and it may be that the growing availability of content actually spurs an increase in demand for that content.

This is just a smattering of examples: Mike Masnick and Chris Anderson have spent some time documenting a number of ways people already make money from free content. ${ }^{39}$ And it is worth noting that what we want from copyright protection is a continual supply of new content. If that content increasingly comes from amateurs as well as professionals, there's nothing wrong with that. It might even make John Philip Sousa proud.

Let me be clear: I don't know what the future of content business models is going to look like. I could do worse, however, than to turn to the words of Marc Norman and Tom Stoppard in the Oscar-winning movie Shakespeare In Love:

Henslowe: Mr. Fennyman, let me explain about the theatre business. The natural condition is one of insurmountable obstacles on the road to imminent disaster. Believe me, to be closed by the plague is a bagatelle in the ups and downs of owning a theatre.

Fennyman: So what do we do?

Henslowe: Nothing. Strangely enough, it all turns out well.

Fennyman: How?

Henslowe: I don't know. It's a mystery. ${ }^{40}$

I don't know exactly how it will turn out, what the future of content industry will be. But I am quite confident that there will, in fact, be one.

38. Kal Raustiala \& Christopher Sprigman, The Piracy Paradox: Innovation and Intellectual Property in Fashion Design, 92 VA. L. REV. 1687, 1733 (2006).

39. Mike Masnick, The Future of Music Business Models (And Those Who Are Already There), TECHDIRT (Jan. 25, 2010, 10:18 AM), http://www.techdirt.com/articles/20091119/1634117011.shtml; CHRIS ANDERSON, FREE: THE FUTURE OF A RADICAL PRICE (2009).

40. MARC NORMAN \& TOM STOPPARD, SHAKESPEARE IN LOVE 23 (1998). 